\title{
Natural Bio-Based Products for Wood Coating and Protection against Degradation: A Review
}

\author{
Carmen-Alice Teacă, ${ }^{\mathrm{a}, *}$ Dan Roşu, ${ }^{\mathrm{a}}$ Fănică Mustaţă, ${ }^{\mathrm{b}}$ Teodora Rusu, ${ }^{\mathrm{a}}$ Liliana Roşu, \\ Irina Roşca, ${ }^{\mathrm{a}}$ and Cristian-Dragoş Varganici ${ }^{\mathrm{a}}$
}

\begin{abstract}
Preservation of wood structures against degradation represents an old, and however, a new challenge. Wood, as a natural hybrid composite material, represents a versatile and widely exploited renewable resource for indoor and outdoor applications. Its constitutive biopolymers are subjected to intense and progressive oxidative degradation processes under environmental conditions of exposure, affecting wood's native durability and generating significant structural and color changes, along with progressive diminution of its resistance against biological agents. One effective way to prevent wood degradation is to apply coating protective layers by chemical modification of the surface. In this context, increasing interest for improving wood coatings behavior under exposure to outdoor applications, when these are able to prevent or limit to a large extent the deleterious effects of environmental factors upon their performance, justifies enhanced research efforts to provide new effective solutions for sustainable wood protection. Recent trends in this area include use of biobased natural products - extractives, oils, waxes, resins, biopolymers, biological control agents - for which the main classification criterion is represented by the type of protection provided, considering the large available variety of such formulations. The present paper focuses on the most recent literature data with significant assessment of specific topics related to these issues.
\end{abstract}

Keywords: Wood protection; Wood decay; Bio-based coatings; UV protection; Hydrophobic properties; Biocide properties; Biological decay antagonists

Contact information: a: "Petru Poni" Institute of Macromolecular Chemistry, Advanced Research Center for Bionanoconjugates and Biopolymers, 41A Gr. Ghica-Voda Alley, Iaşi, 700487, Romania; b: "Petru Poni" Institute of Macromolecular Chemistry, Physical Chemistry of Polymers Department, 41A Gr. Ghica-Voda Alley, Iaşi, 700487, Romania; *Corresponding author: cateaca@icmpp.ro; cateaca14@yahoo.com

\section{WOOD - A VERSATILE MATERIAL AND ITS BEHAVIOR UNDER EXPOSURE TO ENVIRONMENTAL CONDITIONS}

Wood, a biologically self-assembled polymeric structure occurring in nature, presents a hierarchical, and complex designed network consisting of intimately associated biopolymers, which is perfectly adaptable to continuously changing environmental conditions (Fengel and Wegener 2003; Fratzl and Weinkamer 2007). Wood's constitutive biopolymers (cellulose, lignin, hemicelluloses) are subjected to intense and progressive oxidative degradation processes (photo-oxidation, chemical oxidation, thermal decomposition, photolysis reactions) under the action of environmental factors (sunlight radiation, mainly UV component; moisture generated through dewing, raining, and snowing; chemical pollutants; fire; heat/cold variations; wind abrasion-particulates; atmospheric oxygen), which affects wood's native durability (dimensional stability, surface integrity) and causes occurrence of significant structural and color changes (discoloration), 
along with a progressive diminution of its resistance against biological agents (biodegradation or decay development) and its mechanical properties.

One effective way to prevent wood's degradation processes is to apply coating protective layers by chemical modification of the surface. In this context there is increasing interest in the improvement of coatings for wood and their performance under exposure, mainly outdoor applications. In such cases, the coatings may be able to prevent or limit, to a large extent, the deleterious effects of environmental factors upon their performance along with ensuring maintenance of the wood's aesthetical appearance. Prospects of improved production justify the enhanced research efforts made in relation to provide new effective solutions for sustainable wood protection.

The wood preservative industry is interested in finding low-cost, environmentally friendly methods for the treatment of the wood. Plant oil-type wood preservatives are some of the oldest preservatives, and many applications still imply their use. Recent trends in this area include the use of bio-based natural products (such as wood and plant extractives, vegetable oils, natural waxes, different biopolymers, and biological control agents), and nano-based materials, for which the main classification criterion may be represented by the type of protection provided, considering the large available variety of such formulations. The combination of bio-based coating solutions with biological decay antagonists (microorganisms, biological compounds, or enzymes) may provide a relevant innovative solution for wood protection. The present paper focuses on the most recent literature data with significant assessment of specific topics related to these issues.

\section{Wood Degradation Process}

Aging is a generic name used to define the slow degradation process of various polymeric materials, including wood and those incorporating wood in different sizes and forms, under exposure to climatic and environmental factors, but also through action of wood-degrading organisms (insects, fungi, bacteria, and marine borers) (Unger et al. 2001). The mechanism of the deterioration depends on the type of material, but it is usually caused by a synergistic combination of ambient factors. Usually this process involves irreversible changes in physical, chemical, and mechanical properties of a material during extended storage or usage. Chemical changes in the polymer components have effect on the wood microstructure and further promote changes in physical and mechanical properties of wood due to progressive aging process. Storage wood conditions (aerobic, anaerobic), for example, have a significant influence on wood's behavior under environmental exposure because these determine what kind of chemical processes may occur during the aging process (Fengel 1991).

The fraction of ultraviolet (UV) light with wavelengths greater than $300 \mathrm{~nm}$ from the whole solar spectrum is the main promoter of wood aging under environmental conditions. The wood photo-oxidation degradation process starts immediately after exposure to solar light, accompanied by color changes and progressive erosion of the wood surface. UV radiation has enough energy for photochemical degradation of structural polymer components of wood (lignin, cellulose, and hemicelluloses), which have a different behavior during the aging process (Teacă et al. 2013).

UV weathering, a process initiated primarily by the ultraviolet portion of the solar radiation spectrum with intensity and wavelength depending on many uncontrolled parameters that change not only throughout the year but even throughout the day, causes surface photo-oxidation or photo-chemical degradation of wood. This complicated process is further enhanced through wetting and drying of wood through precipitation, diurnal and 
seasonal changes in relative humidity, abrasion by air particulates, temperature changes, atmospheric pollution, oxygen, and different human activities (Williams 2005).

The different aspects of wood aging were recently comprehensively reviewed (Kranitz et al. 2016). The degradation starts immediately after wood exposure to sunlight action. That is why it is essential to understand the chemical nature of wood polymer components, the UV spectrum composition, and the interactions of UV radiation with various chemical structures in wood for a better knowledge of the chemistry of wood degradation under UV exposure conditions (Teacă et al. 2013). Chemical changes can be evidenced by Fourier transform infrared (FTIR) spectroscopy, and in relation with these, color changes are significant for various applications. A new methodology using FTIR spectroscopy was effectively applied to study the age of the carving phase for wood objects, considering analysis of samples from different depths and localizations for an eventual gradient of water absorbed between the surface and the inner part of both ancient and modern wood sculptures (Vartanian et al. 2015).

Primary photochemical reactions occur as a result of the activation of wood polymer chains by direct absorption of light radiation. In an inert atmosphere of nitrogen or argon, degradation reactions occur, including splitting of wood polymer chains and cross-linking, while in the presence of air, oxygen is able to initiate photo-oxidative processes. Photo-oxidative degradation processes of wood polymers take place by radical intermediates. Such reactions proceed every time by following the steps of a chained mechanism as presented in Fig. 1.

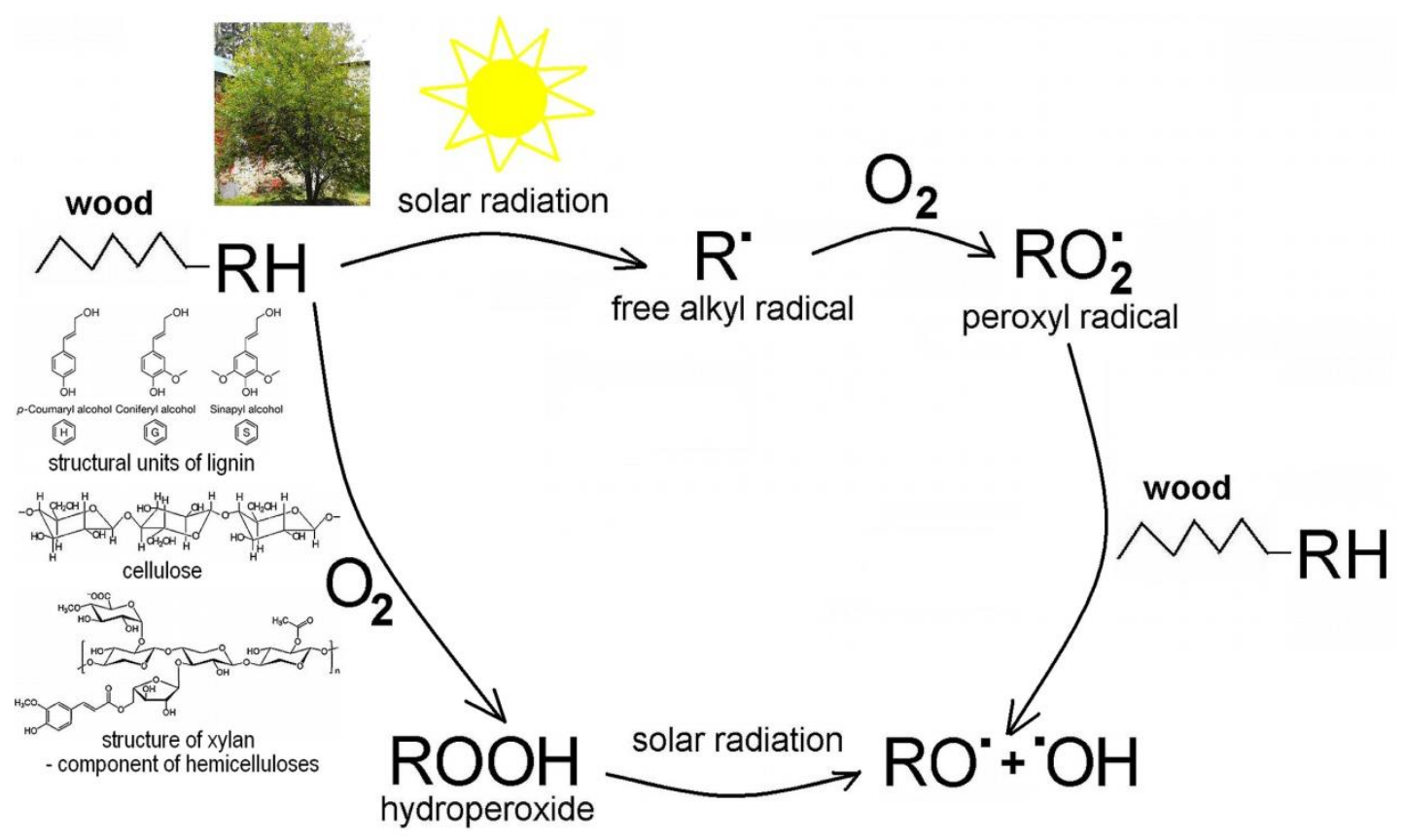

Fig. 1. Photo-oxidative degradation pathway for wood under exposure to sunlight action

Wood products are coated for resistance to UV radiation. Usually, the photodegradation process results in reduced water resistance of wood and wood-based materials and consequently in their further biodegradation under outdoor exposure conditions. The intense damage to materials due to the UV component in solar radiation, mainly an increased UV-B (280-315 nm) radiation level, can be prevented by using light-stabilization 
technologies, surface coatings or, in most instances, by substituting these materials with materials that are more resistant against UV radiation. All these effective modalities generally incur higher costs (Andrady et al. 2011).

Wood, as an organic and heterogeneous material, is very susceptible to mold growth and blue stain fungi under appropriate exposure conditions. The whole production chain of wood-based products is strongly related to their further durability, this including wood quality, processes, structures, and end use conditions. In the end use condition, the humidity, mainly its level and duration of moisture stress, in connection with temperature and exposure time, are often the most critical factors for the mold growth and blue stain on wood surfaces. Anyway, the resistance of wood degraded surfaces to water movement and biological attack by microorganisms (fungi, insects, molds, bacteria, etc.) is decreased by weathering processes. The biological attack of wood surfaces, commonly called mildew, contributes significantly to color change of wood. Initially, no erosion of the surface is noticed, but occurrence of graying or an unsightly dark gray and blotchy appearance is evident, being caused by the growing of dark-colored fungal spores and mycelia on the wood surface. As weathering advances and the wood surface is enriched by cellulose, a silvery-gray patina is developed (Kirker and Winandy 2014).

However, wood decay fungi are able to use the structural components of wood as a food source. For example, lignin breakdown products resulted from the photo-degradation process (Schoeman and Dickinson 1997). Considering their relative importance to wood degradation, wood decay fungi can be classified (Schoeman and Dickinson 1997; Bardage 1998; Mai et al. 2004; Kirker and Winandy 2014) as presented in Fig. 2.

However, wood coloration by fungi can have a positive effect under favorable conditions (water, temperature, nutrients) when fungi are causing degradation of coatings present on the wood surfaces (both through growing on the coatings and/or penetrating them to reach the wood), and act as a physical barrier that effectively protects wood coated surfaces against photo-degradation (Cogulet et al. 2018).

Particular interest has been directed toward Aureobasidium because of its role in the formation of biofinishes on wood, namely uniform dark molds formed on the oil treated wood surfaces under outdoor exposure conditions (van Nieuwenhuijzen et al. 2015), and considered to be an attractive biocide-free construction material that may have self-healing properties.

Wood protection is a foremost topic when it is used for building applications. Function and service life of any wood-based structures depend to a large extent by the interactions between structural design and appropriate wood materials selection, from durability perspectives and in terms of maintenance and aesthetics. Durability of a wood product susceptible to a degradation risk is strongly related to both the intrinsic decay resistance of the wood and the extent of the risk (Scheffer and Morrell 1998). Environmental conditions such as moisture availability, soil parameters, and climate determine the widely variation in wood products durability. For wood structures above ground, the risk of decay can be graded from almost negligible to essentially as extensive as in contact with the ground. The higher the risk of decay, the shorter will be the expected service life for a given wood product.

The risk of wood decay in above ground conditions (e.g. wood used in decking, window frames, and an array of other purposes) is usually assessed on the basis of climate alone by combining rainfall and average monthly temperature in order to calculate the climate index (decay risk) for a given location (Scheffer 1971). The assessment of decay resistance of various wood species require both laboratory pure culture decay tests and 
field tests, but inherent variations in conditions influence to a large extent the results. The wood species can be classified as very resistant (1), resistant (2), moderately resistant (3), and non-resistant or perishable (4).

The main aspect to be considered when designing any wood structure is to control moisture, as most wood-attacking organisms require moderate amounts of water for growth. In above-ground conditions, considered slight deterioration environments, finishes with water repellents in formulation can ensure a good protection of wood. In moderate to extreme locations such as ground contact conditions, durable wood such as chemically treated wood (e.g. impregnation treatments with biocides) or samples from naturally resistant wood species, including heartwood, can successfully replace the degraded wood (González-Laredo et al. 2015).

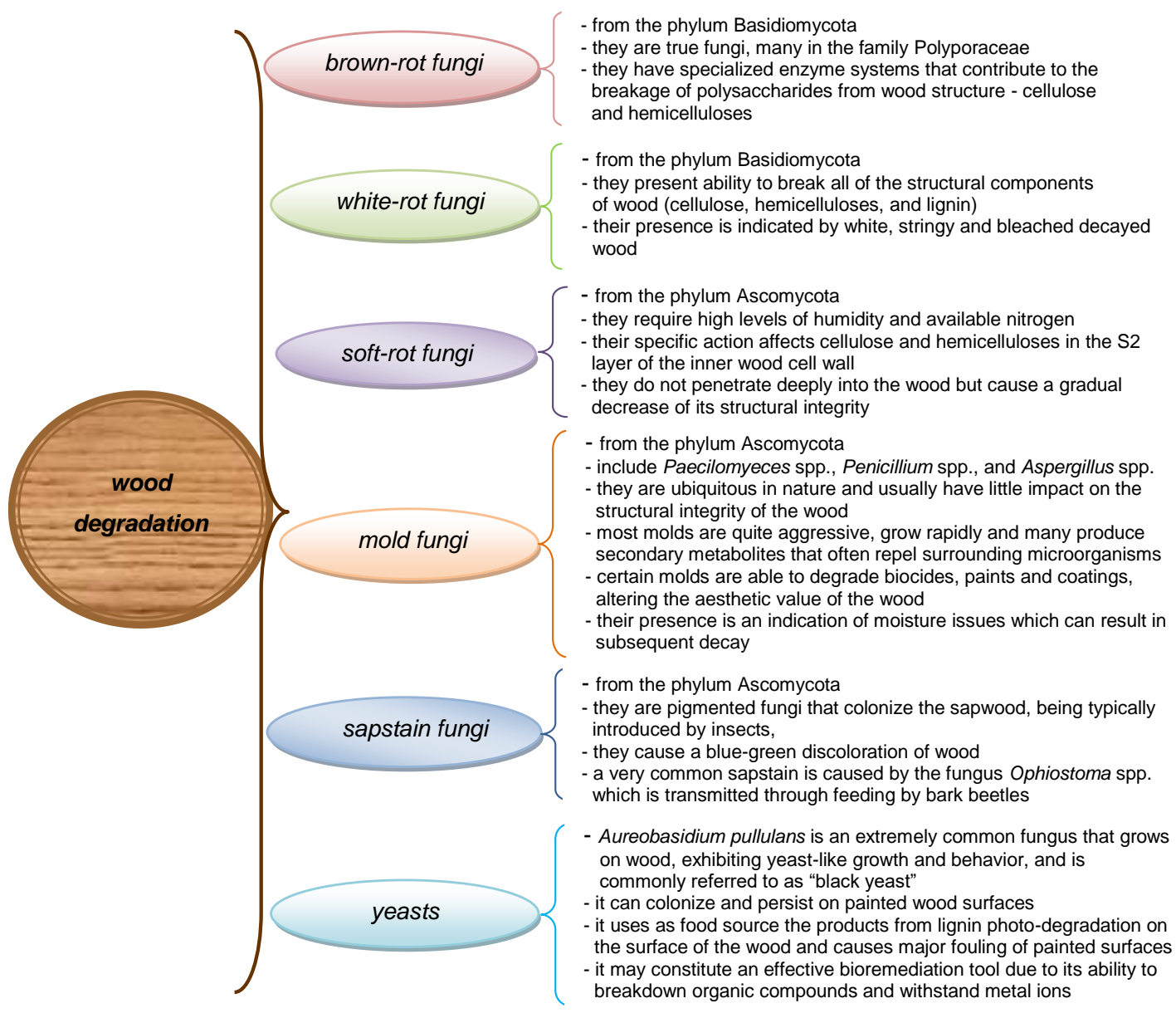

Fig. 2. Wood decay fungi classification depending on their involvement in wood degradation

\section{BIO-BASED COATINGS FOR WOOD PROTECTION USING NATURAL PRODUCTS}

Wood preservation through chemical treatments (e.g. copper compounds) is becoming restricted from an increasing number of applications due to both the pronounced toxicity and harmful effects to the environment. The wood coatings domain represents a 
very active field of research and development, driven by the necessity to produce high performance materials able to respond to competitive challenges, and different environmental regulations and constraints. These critical demands are answered by the moving of this developing area from solvent-based coatings or solvent-free ones to waterborne coatings, from synthetic products to natural ones or even mixtures.

Coatings are usually very complex formulations, consisting of non-volatile and volatile components. The non-volatile part of a coating is composed mainly by a filmformer or a binder. Besides this, there are also parts such as pigments, dyes, fillers, and all kinds of additives, including hardening accelerators, thickeners, dispersants, flow control agents, preservatives, and UV-protecting agents. The volatile part consists of solvents or dispersants, thinners, and some volatile additives (Brock et al. 2010).

Preservative systems based on plant seed oils from natural and renewable sources may confer protection to wood under the action of various environmental factors. Plant oils, as well as natural waxes (e.g. beeswax), as non-toxic substances, can form an environmental friendly and efficient protective layer on the surface of the wood samples, thus improving water resistance of wood and further its dimensional stability.

Traditionally, wood protection against fungi, mildew, moulds, or insects has been effectively ensured by impregnation using different natural substances, such as plant oils, tars, and extracts with varying degrees of protection, but until recently they were not sufficiently promoted (González-Laredo et al. 2015). Natural products for wood protection purposes include plant and wood extracts, essential oils, waxes and resins from bark, and biopolymers (e.g. chitosan), which are environmentally friendly and available in significant quantities, their main disadvantage being represented by their mild leaching capacity from treated wood surfaces. The problem of leaching can be answered by effective approaches (Maoz et al. 2007; Singh and Singh 2010; Reinprecht 2010; Singh and Singh 2012) including in situ polymerization with structural polymers in wood (e.g. enzymatic polymerization of essential oils with lignin in wood) and treatments with nanoparticlesbased media or using mixtures of products. The two approaches can reciprocally enhance each other's actions.

The use of natural products in industrial applications depends, to some extent, on some inherent issues such as disparity between results from laboratory testing and industrial implementation, limited range of protection against biological factors and weathering process, variability in chemical composition within large limits, relatively high costs, and long procedures of registration. Despite the above-mentioned factors that might act as limitations, there is still a constantly increasing interest in identification and using natural products for wood preservation and protection, mainly when these products are environmentally friendly and without risk for the human health.

\section{Extractives from Wood and Plants with Biocide Properties}

Besides the main polymer constituents, wood's chemical composition includes minor amounts of extraneous materials, mostly in the form of compounds known as extractives (usually 4 to $10 \%$, even up to $30 \%$ as a function of wood species, growth conditions, time of year when the tree is cut) and minerals (ash), mainly calcium, potassium, and magnesium, besides manganese and silica (Miller 1999; Nascimento et al. 2013). The extractives comprise both inorganic and organic components, and their content is higher in bark, leaves and roots, than that in stem wood. The extractives contribute to wood properties such as color, odor, taste, decay resistance, density, hygroscopicity, and flammability (Fengel and Wegener 2003; Rowell et al. 2013). Organic extractives of wood 
can be classified into the different groups (Rowell et al. 2013; Matuana and Stark 2015) as presented in Table 1.

Table 1. Organic Extractives in Wood

\begin{tabular}{|c|c|c|c|}
\hline $\begin{array}{c}\text { Aliphatic and Alicyclic } \\
\text { Compounds }\end{array}$ & Phenolic Compounds & Gums & Other Compounds \\
\hline terpenes and & phenols & polysaccharides with & sugars \\
terpenoids (resins & stilbenes & linear structure & cyclitols \\
acids; tropolones; & lignans & polysaccharides with & amino acids \\
steroids) & isoflavones & branched structure & alkaloids \\
fatty acids esters & condensed tannins & polysaccharides with & coumarins \\
(fats; waxes) & flavonoids & branch-on-branch & quinones \\
fatty acids & hydrolyzable tannins & structure & \\
fatty alcohols & & & \\
alkanes & & & \\
\hline
\end{tabular}

These wood components can be extracted from wood with solvents (water, alcohol, acetone, benzene, toluene, ether or mixtures of solvents [e.g. alcohol/benzene or toluene]). Characterization of biologically active components from resistant woods could lead to increased protection of wood from termites through treatments with some extracts or synthesized compounds with structures similar to the active components (Carter et al. 1978). Hardwood and softwood may contain similar amounts of extractives, but the composition differs (Fengel and Wegener 2003). These are present in various ratios as tannins and other polyphenolic type compounds, colored substances, essential oils, fats, resins, waxes, gum starch, and simple metabolic intermediates. Such active compounds include quinones (Carter et al. 1978; Ganapaty et al. 2004), flavonoids (Reyes-Chilpa et al. 1998; Ohmura et al. 2000; Chen et al. 2004; Morimoto et al. 2006), terpenoids (Chang et al. 2000; Watanabe et al. 2005), and alkaloids (Kawaguchi et al. 1989). The natural durability of wood is usually correlated to its extractives content and composition (Carter et al. 1978; Taylor et al. 2006; Santana et al. 2010; Andrady et al. 2015). When a comparison is made between natural extractives compounds from wood and plants and common substances used for wood preservation in terms of effectiveness, the natural ones mentioned are generally favored for safety and have versatile applications, considering both their biocide and antioxidant character, as well as their metal binding ability (Kartal et al. 2006; Syofuna et al. 2012; González-Laredo et al. 2015; Sablik et al. 2016). These extractives act by decreasing the hygroscopic character of wood surfaces and thus inhibiting decay activity for a wide range of biological organisms such as human pathogens, insects, or fungi, with a positive impact upon wood durability. Heartwood extractives may exhibit significant antifungal and antioxidant properties (Schultz et al. 1995; Schultz et al. 2002). Specific applications for wood and plants extractives (CarrilloParra et al. 2011; Nascimento et al. 2013; González-Laredo et al. 2015; Sundararaj et al. 2015) include long-term preservation (for condensed tannins), antifungal and subterranean termites protection (for flavonoids), repellency and toxicity against termites (for quinones), and resistance of heartwood to fungal decay (for stilbenes). The method and solvents used for extraction may influence to some extent the initial antifungal activity of different groups of extractives.

There are native extractive compounds such as those obtained from the heartwood of durable species such as black locust (Robinia pseudoacacia L.) and African padauk (Pterocarpus soyauxii Taub.) that show enhanced antifungal activity in laboratory testing 
conditions by increasing the durability against decay of impregnated European beech (Fagus sylvatica L.) wood samples (Sablik et al. 2016).

The presence of condensed tannins (proanthocyanidins or polyflavonoid tannins) in the bark extract from mimosa (Acacia mollissima) and quebracho heartwood extract (Schinopsis lorentzii) is effective for conferring an enhanced fungal resistance in testing against both white and rot fungi due to their significant amount (Tascioglu et al. 2013; González-Laredo et al. 2015). These extractive compounds were shown to be effective as wood anti-decay agents in indoor applications even when present at reduced content (Tascioglu et al. 2012).

Extractives from heartwood of some Amazonian woody species (Rodrigues et al. 2012) exhibit some anti-fungal activity in testing against soft-rot, brown rot, and white rot fungi similar to that evidenced by using commercially preservative coatings products.

The camphor tree (Cinnamomum camphora) leaf extract is rich in biological compounds (terpene alcohols: terpineol, linalool, and 4-terineol; a monoterpenoid: eucalyptol named also cineole; a terpene ketone: camphor) acting as effective biocides, with enhanced antifungal activity limited by their volatility and poor thermal stability. In such context, it is necessary to use of some fixing agents (i.e., melamine-modified urea formaldehyde resin pre-polymers). Such compounds exhibit good resistances to decay and insects when used as bamboo preservatives with positive impact on the resulted mechanical properties (Xu et al. 2013).

For enhancement of the antifungal activity, a combination of certain metals (acting as chelators for some fungal enzymes) with biocide extractives (condensed tannins or proanthocyanidins; gallic acid derivatives derived from the tannic acids) is effective mainly when these exhibit a synergistic action (González-Laredo et al. 2015). Another effective method to improve the antifungal action of the wood extractives is addition of the antioxidants acting as scavengers for the free radicals involved in wood decay caused by fungi (Morris and Stirling 2012).

An extractive compound from the neem tree (Azadirachta indica), present in the seeds, leaves, and bark acts as a biocide against fungi, per se or in combination with copper sulphate and boric acid (Islam et al. 2009). It is effective as an insect repellent (against termites, wood borers, and other insects).

The effectiveness of wood extractives as fungicides is related to the environmental and biological factors, as their antifungal activity depends on their ability to impede fungal cells development by inhibiting enzymatic processes and other phenomena occurred on wood substrates. It was evidenced that for interior applications multi-component biocide systems (e.g. including natural extractives and synthetic antifungal agents) can protect wood from decay fungi, mould fungi, and termites (Clausen and Yang 2007).

Overall, the use of wood extractives as UV stabilizers at large industrial scale is limited due to their easy leachability from wood and their high solubility in water. 


\section{Wood extractives as insect repellents}

Extractives from various wood species can be very effective as wood preservatives against wood-attacking insects (beetles, termites, borers, ants). Toxicity of the extractive compounds is strongly related to the wood-derived species and their extraction methodology, a fact evidenced by the effectiveness of some extractives used for treatment of tropical wood species (Pinus caribaea, Antiaris toxicaria), which were tested against termites attack (Syofuna et al. 2012). Flavonoids separated from Larix wood species such as taxifolin, aromadedrin, and quercetin (Ohmura et al. 2000) and isoflavonoid derivatives such as pterocarpans (Morimoto et al. 2006) from heartwood of Pterocarpus macrocarpus Kurz (Leguminosae) are deterrents against subterranean termites. Naturally extracted solutions obtained from mimosa (Acacia mollissima Wild.), and quebracho (Schinopsis lorentzii Griseb., a very strong hardwood tree species) were shown to be effective by testing resistance against subterranean termites (Reticulitermes grassei) after their applying them for treatment of beech and pine wood samples (Tascioglu et al. 2012).

The biocidal action of some wood extractives against termite attack is enhanced when also considering their antioxidant properties. Thus, extractives separated from mangrove bark (Rhizophora apiculata), after dewaxing with methanol and partitioning with other organic solvents yielded in polyphenol type compounds with antioxidant activity that conferred resistance to termites attack (Khalil et al. 2009). Overall, the role of natural extractives as wood protective agents against biodegradation is strongly dependent on their chemical composition and location in the heartwood parts.

\section{Tannin-based wood preservatives}

Tannin-based wood preservatives have been used since the last decades of the last century, but their applications were limited by their high solubility in water (Laks et al. 1988; Pizzi 1994). Nevertheless, tannins present a hydroxy-aromatic structure suitable for resin formulations that confers them reactivity in the presence of hardeners, such as formaldehyde or hexamine, a feature common to that of other phenols (Pichelin et al. 1997; Tondi et al. 2009a). Besides this feature, tannins present a good ability to coordinate heavy metals ions with formation of stable complexes (Yamaguchi and Okuda 1998; Tondi et al. $2009 \mathrm{~b}$ ). Use of tannin-boron compounds as wood preservatives was considered and investigated as both their biological activity and further efficiency for protection of wood in outdoor applications (Thevenon et al. 2009). Tannin-based compounds can be effectively bounded in the wood cell walls by using hexamine as hardener (Pichelin et al. 2006). Such formulations impregnated on wood samples may have a positive impact on the resulting mechanical and fire resistance properties (Tondi et al. 2012) with successful potential applications for wooden building preservation.

Some tannin-based formulations comprising sulphide derivatives of catechins and cupric complexes presented an effective biocide action when testing against wood rotting fungi and bacteria (Laks 1991). Halogenated tannin extracts imparted a good resistance when used to treat wood samples and testing against all above-mentioned conditions, as well as towards insects attack and weathering process (Lotz 1993). Chemically modified tannins inhibited enzymatic activity of enzymes involved in biodegradation of wood polysaccharide components, namely xylanases, mannases, and cellulases (Yamaguchi and Yoshino 2005). 


\section{Miscellaneous}

Cashew nut shell liquid (CNSL) with 30 to $35 \mathrm{wt} \%$ oil in composition represents a valuable agro-waste produced from cashew nut shells, being also a significant source of unsaturated phenols, as well as a very promising renewable resource for synthesis of various important industrial chemicals such as paints and varnishes, brake linings, coatings, phenolic and epoxy based resins, or wood adhesives (Mubofu and Mgaya 2018). It was investigated as a modifier for phenol-formaldehyde resins (Rao and Palanisamy 2013).

Other extractive compounds from plants, such as diols, may be effectively used as coatings for wood protection in outdoor applications. Weathering tests performed on pine sapwood samples coated with polyurethane dispersions based on 1,3-propane diol, and 1,6hexane diol, respectively, derived from corn sugar (Nakamura and Whited 2003; Daniliuc et al. 2012), showed a better resistance of samples with no evident damage even after 15 months of exposure. An enhanced durability was achieved by applying dispersion resulted from mixing pure acrylics and flexible polyurethane on the wood samples (e.g. resistance to hail).

\section{Plant Oils for Wood Protection}

Since ancient times, plant oils have been known and widely used for various purposes (e.g., lighting, cooking, wound care, cosmetics). Some oils present the ability to form films depending on the plant species and location of growth, being suitable for coating applications. Such oils are mainly triglycerides, which vary with respect to the contents of different fatty acids in esters and their degree of unsaturation or more specific, as the number of diallylic methylene groups in the molecular chain (Olsson 2012). There are three main categories of oils with film forming ability, namely drying oils (addition of a siccative or oil drying agent favors the hardening of drying oils by promoting the free-radical auto-oxidation process of the oils with air), semi-drying oils, and non-drying oils. The two first mentioned oils types are usually used for wood impregnation and as binders in paint and varnish formulations. The semi-drying and the non-drying oils are effectively used as modifiers of alkyds and as plasticizers in nitrocellulose-based coatings (Bulian and Graystone 2009).

Oils from vegetal resources can be highly efficient for applications in wood protection and preservation due to their antifungal and antibacterial properties, these acting also against termites and nematodes attacks, and being effective water repellents and screens/stabilizers against UV radiation (Macias et al. 2005; Kartal et al. 2006; Hyvönen et al. 2006; Lyon et al. 2007; Lin et al. 2007; Hyvönen et al. 2007a,b; Nakayama and Osbrink 2010; González-Laredo et al. 2015). They can be used per se or in various combined formulations with synergetic action such as complexes with metals (Roos and Archer 2004) or with ammonium borate compounds (Lyon et al. 2009).

Still, given the fact that oils only fill the wood cavities by capillarity, not being chemically bonded to the wood cell walls, it is necessary to ensure a high ability of oil retention in order to acquire the required protection (Demirel et al. 2016). In the following, some specific applications of drying oils will be presented.

\section{Drying oils}

Drying oils are used for wood protection per se or as a significant part of the oilmodified polyester resins, known as alkyds, which may be either crude or chemically/ thermally modified. Drying oils may undergo an auto-oxidation reaction under air exposure in ambient conditions when deposited onto the surface to be protected, forming a structural 
tri-dimensional network through cross-linking. This reaction proceeds as a radical chain reaction, evolving in three stages, initiation, propagation, and termination, sometimes accompanied by degradation reactions (Bulian and Graystone 2009).

Some of the highly conjugated polymeric networks are UV-sensitive, being prone to yellowing or discoloration. The higher the content in linoleic acid with two double bonds in the structure, the greater the probability the resulting film undergoes photochemical degradation. When the final network contained ether bridges up to some extent, the resulting coating is more stable and resistant towards water and alkali. For example, films obtained from siccative tung oil are able to dry within short intervals and have good properties, but, on the another hand, tung oil is more expensive than other siccative oils (Thanamongkollit 2008).

Vegetable oils have been used and investigated for specific applications in wood preservation. The most commonly studied natural oils available for wood protection purposes have been linseed oil and tall oil. Many other vegetable oils, including soybean oil, nut oil, hemp oil, parsley seed oil, pomegranate seed oil, Nigella sativa oil, canola oil, sesame oil, were tested in order to evaluate their preservative potential under exposure to artificial weathering process (Ozgenc et al. 2013). Linseed oil, tall oil, orange oil, soybean oil, nut oil, and hemp oil proved to be efficient for wood preservation (Treu et al. 2001; Nakayama and Osbrink 2010), mainly against decay and termites (Yamaguchi et al. 1999; Kartal et al. 2006; Chang et al. 2008; Sen and Yalçin 2010). Orange oil, derived from the skin of an orange peel, is usually used to clean and treat wood furniture.

Tall oil, linseed oil, and tung oil are very efficient against water uptake when used for treating wood surfaces (Hyvönen et al. 2006; Koski 2008; Humar and Lesar 2013).

Tall oil is a by-product obtained during the kraft pulping process of coniferous trees and, basically, is a complex mixture of fatty acids (mainly palmitic acid, oleic acid, and linoleic acid) and fatty alcohols, resin acids (mainly abietic acid and its isomers), unsaponifiable sterols, some sterols, and other alkyl hydrocarbon derivatives (Temiz et al. 2007). Its application as a wood protective agent is related to the presence of some structural components that are similar with heartwood extractives, the principal source of decay resistance (van Eckeveld et al. 2001; Hyvönen et al. 2006). Its efficient action in conferring wood resistance towards weathering process is enhanced when mixing it with linseed oil (Koski 2008).

In common practice, most vegetable oils are easily colonized by microorganisms, which cause color changes and degradation of the oil-based coatings, as well as wood substrate (Brischke and Melcher 2015). Therefore, modification processes through chemical and thermal methods are effectively applied to vegetable oils involved in coating formulations (Bulian and Graystone 2009).

One of the most used methods for oil chemical modification is epoxidation; the new formed epoxide groups are more reactive than the initial carbon double bonds, thus rendering the oils as good plasticizers. Among various epoxidation methods, including the conventional reaction of an alkene with an organic peroxide acid, or methods involving an acid ion exchange resin (AIER) or a metal catalyst, the chemo-enzymatic epoxidation has achieved great interest since this method is non-harmful and environmentally friendly, and its conversion rate is usually over $90 \%$ (Tan and Chow 2010). The most commonly used are the epoxidized soybean and linseed oils (ESO and ELO), these being efficiently used to formulate an UV-protection system; the oils are uses as-is or in a combination with 2hydroxy-4(2, 3-epoxypropoxy)-benzophenone (HEPBP) (Olsson 2012; Olsson et al. 2015). The epoxidized linseed oil is also efficient as hydrophobic agent in combination 
with biocides, forming a suitable protective formulation for timber in both above- and inground exposure (Panov and Terziev 2015). The efficient wood protection against UV light action was noticed for epoxidized soybean oil when applied for wood treatment previously chemically modified for hydrophobization by reaction with succinic anhydride (Roşu et al. 2016).

Wood samples modified with succinic anhydride and further impregnated with epoxidized grapeseed oil exhibited a superior thermal stability and decay resistance against fungi such as Penicillium chrysogenum and Cladosporium cladosporioides (Roșu et al. 2018).

A very effective method for treatment of wood in order to achieve enhanced resistance in outdoor applications involves applying the thermal treatment using vegetable oils, when oil penetrates the wood structures, with limitation of the oxygen amount (Esteves and Pereira 2009; Gérardin 2016). The combined effects of heat and vegetable oil include enhanced resistance to fungal and moulds, as well as better resistance against termites, marine borers and other insects; improved mechanical characteristics; limited weathering and hygroscopicity; good dimensional stability; and reduced cracking (Bazyar 2012).

\section{Wood Treatment with Waxes}

Waxes are usually used as hydrophobic coating material in the wood industry, being easy to apply, or as an additive in different coating formulations to preserve the appearance (gloss) and softness of wood, alongside efficient hydrophobization (Liu et al. 2011). They consist of a complex mixture of long-chain lipophilic compounds, soluble in organic solvents or dispersible in water, yielding in low viscosity liquids upon melting which are able to form a water repellent coating with protective properties, and to maintain the original aspect and structure of the wood (Bulian and Graystone 2009).

For example, beeswax (BW) contains a wide variety of compounds including longchain alkanes, acids, esters, polyesters, and hydroxy esters. Waxes do not form a typical film on the surface of wood, but after repeated depositions, and in combination with UV radiation and other factors in service, a noticeable layer can gradually build up, sometimes described as "patina", although it has nothing to do with the metal-based (i.e., copper) coating known as "patina".

Waxes and wax emulsions are also used for non-biocidal protection of wood surfaces in outdoor applications, as it is well-known that they increase the water resistance and contribute to the diminution of the photochemical degradation extent. The beeswax also exhibits biocide properties when applied to wood surfaces (e.g. poplar and beech wood samples) exposed to soil burial degradation conditions (Németh et al. 2015).

The hydrophobic effect induced by the beeswax when it is applied on the wood surfaces is more significant in comparison with vegetable oils, for example soybean oil (SBO) and Asclepias syriaca seed oil (ASSO), as reported in a preliminary study (Teacă et al. 2018).

\section{Natural Resins and Modified Natural Resins}

Resins from natural resources (plants or animals) are often confused with gums, although their structure and properties are clearly different. Plant resins are usually synthesized by coniferous plants and contain terpenes and derivatives, soluble in hydrocarbon solvents (such as turpentine) and sometimes in alcohol. An exception is given by okoumé resin, a semi-hard and dry resin having triterpenoids and ethereal oils in 
composition, present within the flaking aromatic bark from Aucoumea klaineana (namely angouma, gaboon, or okoumé), a hardwood tree species in the family Burseraceae, native to equatorial West Africa. This species is a weak wood, with low decay resistance and moderate dimensional stability.

Plant resins are transparent in solid or semi-solid states and present an amorphous chemical structure. The most common plant resins include amber (which is also considered a fossil), oleoresins, balm of Gilead, Canada balsam (Canada turpentine or balsam of fir), Boswellia resin, copal resin (from Protium copal and Hymenaea courbaril trees), dammar (hard resin from Dipterocarpaceae trees), frankincense (from Boswellia sacra), etc. Shellac and lacquers are examples of resins from animal sources.

The most frequently used resins in coatings formulations for wood preservation and protection include: shellac (produced by insects such as Laccifer lacca, Coccus lacca, and Kerria lacca during infestation of some specific trees), colophony (rosin oil obtained from pines and other coniferous plants), and dammar (a hard resin obtained from Dipterocarpaceae tree by incision). Moreover, copal ones (from soft to hard), kauri, Venice turpentine (from Larix decidua), benzoin (Styrax trees), mastic (Pistacia tree), sandarac (Tetraclinus cypress tree) are also known for their conservation properties. The current trends in wood coatings indicate the limited role of natural resins, but they are still in use in some sectors for varnishes and as components in complex formulations in order to modify some properties of the coatings (Bulian and Graystone 2009).

\section{Biopolymers in Coatings Formulations for Wood Protection}

Biopolymers, such as chitin, chitosan, starch, gelatin, and zein, etc., represent a viable alternate solution for wood coating formulations both in terms of commercial and protective efficiency (Bulian and Graystone 2009). One advantage of using biopolymers in wood conservation and protection is related to their high compatibility with polar adhesives. They also have improved biodegradability at the end of the life cycle, and the highly polar surface of the wood has a good affinity towards protein-based or cellulose derivate biopolymers.

Methods to overcome some drawbacks when using biopolymers in coatings formulations for wood protection (e.g. insolubility in water or solubility in acid solutions that cause inherent hydrolysis of cellulose and hemicelluloses; high viscosity of their solutions) are already effectively applied. For example, ionic liquids are used as efficient solvent media for biopolymers with the aim to better preserve wood surfaces (Stasiewicz et al. 2008; Garcia et al. 2010; Croitoru et al. 2015), as well as to prove their effectiveness in the protection of wood against UV radiation (Patachia et al. 2012).

Chitosan, a linear biopolymer derived from crustacean shells, can be useful per se or as additive in antifungal formulations for wood preservation, conferring some level of protection (Laflamme et al. 2000; Alfredsen et al. 2004; Eikenes et al. 2005; Larnøy et al. 2005). Chitosan with high molecular weight seemed to be more active against wood decay fungi than chitosan with low molecular weight (Eikenes et al. 2005). An interesting research direction was to use the chitosan for wood protection against mold fungi (Penicillium chrysogenum, Aspergillus flavus, Aspergillus niger) in historic artifacts localized in Egyptian dry environments (El-Gamal et al. 2016), its efficiency being wellcorrelated with its increasing concentration.

For an efficient physical and chemical stabilization of chitosan on the wood surface that confers an enhanced antifungal protection, it is required to use it in combination with 
other polymers, e.g. polyethylene glycol (PEG), which initially reacts with wood, thus creating anchors for chitosan (Nowrouzi et al. 2016).

An interesting approach is to use lignin, a biopolymer isolated from the wood structure, as a UV stabilizer in wood coating formulations (Schaller and Rogez 2007). Phenols leached from lignin can be absorbed by treated wood surfaces and act efficiently as biocides when testing against rot fungi (Chirkova et al. 2011). Lignin ester-based derivatives, such as lignin modified by reaction with lauroyl chloride, can be efficiently used as hydrophobization agents on the wood surfaces in protective coatings formulations (Herrera et al. 2016). High performance coatings with improved thermal stability, better film-forming ability, enhanced hydrophobization action, as well as high adhesion towards wood surfaces are represented by high-lignin-content bio-based polyurethane systems (Griffini et al. 2015).

Protein-based biopolymers, such as zein (a hydrophobic protein extracted from maize), and gelatin (a mixture of animal peptides and proteins obtained by the partial hydrolysis of collagen) can be efficiently used for wood surface protection, mainly when an ionic liquid (1-ethyl-3-methylimidazolium chloride) is used as solvent-carrier (Croitoru et al. 2015). They are able to form uniform coatings that confer higher moisture resistance, dimensional stability, and greater hardness of impregnated wood comparative with nonimpregnated wood.

\section{Biological Control Agents (BCA's) for Wood Preservation and Protection}

In the recent decades there has been increasing interest in developing alternative technologies for wood protection in outdoor applications, mainly envisaging prevention of microbial degradation of wood by biological means, with fulfillment of the human and environmental safety requirements, as well as considering its major economical impact. Biological control of wood degradation can be as effective as chemical protection as evidenced by many laboratory and pilot scale experiments (Bruce and Highley 1991; Yang et al. 2007; Zaremski et al. 2011).

Biological control is an innovative approach using biological decay antagonists, namely microorganisms such as fungi and bacteria, against wood-degrading biological agents, such as insects, molds, and fungi (Cook and Baker 1933; Yang 2009; Susi et al. 2011). Integration of this method with the others already in use has represented the main goal for multiple directions involving theoretical and applied research (Score et al. 1998; Brown and Bruce 1999; Phillips-Laing et al. 2003; Singh and Chittenden 2008; Reinprecht 2010; Panek et al. 2014; Stenbæk 2015). Use of such agents has been rather widely applied in agricultural practices, but it has been used only to a limited extent for the protection of timber (Bruce 1997).

Wood is an organic and heterogeneous material and susceptible to mold growth and blue stain fungi. The whole production chain of wood-based products affect the durability: wood quality, processes, structures and end-use conditions. Referring to the last mentioned, mainly in outdoor applications, humidity, temperature, and exposure time are often the main favoring factors for the mold growth and blue stain on wood surfaces.

A previous review (Mai et al. 2004) referred to the biotechnological developments in the utilization of antagonistic organisms for wood protection. These envisaged the enhancing treatability of wood with preservatives and replacement of usual chemicals with biological control agents, the production of bio-glued or adhesive-free board materials through the application of fungal cultures and isolated fungal enzymes, as well as the disposal of preservative-treated wood. 
Wood protection is usually realized using living microorganisms or with active compounds isolated from these microorganisms (Susi et al. 2011). For example, the fungal antagonists against wood-degrading fungi usually tolerate a large variety of conditions, compete effectively for nutrients, and produce antimicrobial compounds during their life cycle, but may themselves affect the appearance (e.g. staining) of the wood surfaces.

According to Cook and Baker (1983), it is important to approach the biological control on the basis of three strategies: biological control of the fungal inoculum, biological protection of wood surfaces, and cross-protection/induced resistance.

Trichoderma is a genus of fungi present in soil as the most prevalent and avirulent opportunistic cultivable fungi (Harman et al. 2004). Different investigations have tested various species in this genus and have presented evidence of their effective action against wood-degrading fungi (white-rot, brown-rot, and dry-rot fungi), but the approach is still under evaluation.

For example, Trichoderma harzianum was tested on Ponderosa pine sapwood against white-rot (Trametes versicolor) and brown-rot (Gloeophyllum trabeum) fungi (Canessa and Morrell 1997). A slow inhibition of their enzymatic activity was evidenced, alongside a significant decrease of weight loss, but the wood decay was not avoided. In the case of the dry-rot fungus Serpula lacrymans, Trichoderma harzianum prevented the colonisation of Serpula, but wood decay was not inhibited (Score et al. 1998).

The mechanism of Trichoderma action seems to be the release of inhibitory volatile organic compounds (VOC's) produced by the Trichoderma isolates (Humphries et al. 2002). It is known that aldehydes and ketones with 7 to 10 carbon atoms in chemical structure (as heptanal, octanal, nonanal and decanal, and related ketones) can inhibit the growth of a wide range of brown and white-rot fungi. A previous study evidenced the effective action of secondary VOC's released from microorganisms against some fungi (El-Fouly et al. 2011). Besides such compounds, the microbial secondary metabolites can represent effective biocontrol agents against sapstain fungi (Bruce et al. 2003; Evans et al. 2008). Some studies referred to the use of effectively crude culture filtrates (Ejechi et al. 1998; Moita et al. 2005).

Trichoderma viride was shown to be effective against certain sapstain and basidiomycete decay fungi in laboratory testing (Schoeman et al. 1994). A large-scale experiment designed to assess the biological control potential of Trichoderma viride against wood staining fungi, under field conditions and associated accelerated decay test conditions (Brown and Bruce 1999), evidenced its significant effect on the rate of sapstain colonisation of Scots pine wood, comparatively with Sitka spruce wood, and considered their different behavior as substrate for growth of staining fungi (Breuil 1998). As staining fungi produce lipases to cleave wood triglycerides into fatty acids and glycerol that are to be further used as nutrients in their growth, the competition for nutrients between Trichoderma species and staining fungi is contributing to the biological control along with the release of VOC's, enzymes and soluble antibiotics (Wheatley et al. 1997).

It was reported that isolates of Trichoderma species, mainly those from $T$. harzianum, were effective in controlling the sapstain proliferation, these being more effective than the usual fungicide treatment when applied on debarked logs (Vanneste et al. 2002). Various species of Trichoderma were able to inhibit the growth of Serpula lacrymans, one of the most important wood decay fungi that can modify lignin and initiate the depolymerisation of cellulose and ultimately to destroy it, on a range of different media (Score and Palfreyman 1994; Palfreyman et al. 1995; Score et al. 1998). This kind of action 
is observed even in the absence of direct contact between $S$. lacrymans and Trichoderma species (Phillips-Laing et al. 2003).

A successful application of Trichoderma spp. is strongly related to its mode of implementation, as it influences to a large extent the distribution of the BCA's in relation with the compartmentalization of the pathogenic fungi (Bruce et al. 1991).

The efficiency of Trichoderma viride against wood decay fungi Gloeophyllum sp. and $G$. sepiarium showed a total inhibition of these by means of mycoparasitism and competition for nutrients (Ejechi 1997).

Currently, Trichoderma spp. is the most extensively investigated species as BCA's for wood preservation purposes, these sharing almost 50\% of fungal BCA's market (Verma et al. 2007). These were more effective against certain wood decay fungi as compared to other antagonistic fungi, e.g. Penicillium sp. (Bruce and Highley 1991).

Aureobasidium sp. is a ubiquitous black, yeast-like fungus that stains wood. It is usually present on the surface of the treated wood, placed above the soil. It is used in biological control of plant diseases and is important in biotechnology for the enzymatic production of different compounds, namely siderophores and pullulan (Chi et al. 2009). This fungus is able to proliferate outdoors on oil treated wood, yielding a uniform dark mould coating biofilm, which may be considered as wood biofinish (Sailer et al. 2010; van Nieuwenhuijzen et al. 2015). Aureobasidium melanogenum (formerly known as Aureobasidium pullulans var. melanogenum) was predominantly present on wood samples treated with oils (linseed oil, olive oil) under outdoor exposure (van Nieuwenhuijzen et al. 2016), regardless of the presence of a biofinish and the type of substrate. This fungus is also effective against wood blue staining fungi (Stenbæk 2015).

Aureobasidium pullulans is able to yield in homogeneously colored biofilms on top of linseed oil treated Pinus sylvestris wood samples after 36 months of outdoor exposure (Sailer et al. 2010). In this investigation, A. pullulans formed a self-healing coating, and was able to grow and maintain itself over the mentioned period of 36 months, without destroying the wood substrate. This is probably due to the strong interactions between the biofilm, oil and wood, which allow the coating to become well-attached to the substrate, without impending peeling and cracking.

Another example of effective BCA's for wood protection is represented by various albino strains of fungi. Many isolates of Ophiostoma floccosum, Ophiostoma piceae, and Ophiostoma pluriannulatum were shown to be effective in preventing the competing fungi from staining the pine wood chips, namely Leptographium procerum, Ophiostoma piliferum, and Sphaeropsis sapinea (Held et al. 2003).

Albino strains of Ceratocystis resinifera (a sapstain fungus that proliferates deeply and rapidly in freshly felled coniferous trees), named Kasper, might be used as an additional source of BCA's against a wild-type sapstain fungi in spruce logs (Morin et al. 2006). Biological control of sapstain using different organisms, such as bacteria or nonrelated fungi, is more complicated because environmental conditions can favor the proliferation of the wood degrading fungi to the detriment of the BCA.

\section{Current Markets and Demands for Wood Coatings}

The global wood coating market is projected to be valued at around \$1,985.28 million by 2020 (Top Market Reports 2015). The major drivers of this market are expected to be growth in the protective coating market (e.g. increasing demand for eco-friendly wood coating products) and the rise in new construction activities, including renovations and remodeling, worldwide. 
Wood coatings are chemical formulations that are used for multiple functions in wood processing when a high quality wood surface is required by purposes such as better stabilization, hygiene, and decoration of wood. The main factors contributing to the development of wood coating industry include building and infrastructure, furniture, and food packaging applications, as well as the stringent necessity of ensuring of a good protection against fungi and other harmful organisms. Among the different technologies and materials (water based systems, solvent based systems, and radiation cured systems) used for conferring a suitable resistance to wood structures under environmental conditions exposure, UV curing is a significant method for wood coatings.

Wood coatings production continues to grow due to a rebound in residential construction activity. The major applications in which wood coatings and preservatives are used include furniture, decking, and siding. It is estimated that further advances will be restrained by the rising use of non-wood materials in several key applications. Coatings and preservatives will be limited in siding applications. Wood still dominates the decking applications, even with increasing use of plastic composites for such purposes. The request for new wood coatings and preservatives in construction-related applications will be the foremost motivation for giving a boost to demand benefits (Coatings World 2019).

Positive trends, such as new home construction, the rise in home values, and remodeling as an expression of personal style, certainly have a positive effect on the architectural coatings industry. In this context, there is increasing interest in interior and exterior finishes of wood surfaces (e.g. staining and restoring decks and floors; repurposing/reclaiming furniture and décor; trend of bringing indoor design elements to outdoor spaces - open floor concepts outdoors with multicolor stained decks, special lighting, furniture, and even kitchens). There is a growing tendency on the wood coating market to offer products that both protect against mildew and UV damage and confer longlasting beauty for the outdoor wood structures, these being able to efficiently handle environmental factors year after year (e.g. water, sunlight, snow, wind, and particulates).

\section{CONCLUSIONS AND FUTURE PERSPECTIVES}

Coatings are essential for the most solid wood or wood-based products utilized in outdoor applications. Besides conferring the desired aesthetical properties (color, gloss, smoothness), coatings are of vital importance in the protection of wood against environmental factors, such as humidity, solar light irradiation, temperature variations, biological decay, and damage of structural integrity that occurs through mechanical or chemical processes. However, different coating technologies provide different levels of protection, for example a comparison of clear coatings and the opaque coatings show that opaque coatings confer more durability. More than $95 \%$ of exterior wood coatings are applied as liquid coatings, either solvent- or water-borne (e.g. acrylic, polyurethane, alkyd), but their use and subsequent emission of volatile organic compounds (VOC's) has represented a dominant concern because of their significant contribution to global warming by the ozone depletion in the stratosphere.

Market studies estimated an important increase in the demand for wood protection coatings and preservatives. Paints are dominant in siding, windows, and doors applications, while dyes and sealers are more widely used on decks, cabinets, furniture, and flooring. Oil-based preservatives are efficiently utilized for industrial applications (railroads, utility 
poles), while water-based treatments are preferred for wood in residential and nonindustrial applications.

The performance of a coating on a wooden surface in outdoor applications is influenced by the same environmental factors, as well as by the type and intensity of exposure, species, and quality of wood, design and processing of the wood structures, properties of the coating (e.g. glass transition temperature of the coating, thickness, permeability, addition of pigments, dyes or UV absorbers), and its corresponding processing and maintenance, etc. All these factors are acting synergistically on coatings, yielding in weathering which can cause photochemical degradation, cracking, flaking, and erosion of the coating, delamination, as well as color changes with occurrence of discoloration, followed by the wood degradation.

Design of a high performance coating able to fulfill the needed sustainable requirements, including both resistance against weathering and maintenance of aesthetic appearance, is very difficult to formulate based on a single concept idea capable of mediating all the above-mentioned inter-related factors that act on coatings in outdoor applications.

The inclusion in coatings formulations (mainly water-borne ones) of natural extractives, vegetable and essential oils, natural resins and waxes, and various biopolymers, makes it possible to prevent or to limit the harmful impact of these formulations on the environment given their specific characteristics (e.g. non-toxicity, reversible character, resistance to moisture and solvents, compatibility). In the recent decades, an increased interest in developing alternative technologies for wood protection in outdoor applications has been apparent, mainly when envisaging prevention of microbial degradation of wood by biological means (e.g. using biological control agents BCA's), with fulfillment of the human and environmental safety requirements, as well as considering its major economic impact. Biological control of wood degradation can be as effective as chemical protection.

Recent modern scientific approaches (e.g. sol-gel chemistry, water-borne micelles, micro-emulsion reactions, self-assembled structures, nanomaterials, and nanotechnology, etc.), focus on combining various materials and techniques, considering their advantageous synergistic action. Thus, it is possible to obtain multi-function coatings able not only to protect current wood, but to also contribute to the recovery, restoration, and preservation of wooden objects from the cultural and archaeological patrimony.

Nevertheless, there are still unresolved problems that need a thorough investigation such as the stability of coatings and their leachability. Another important issue is the targeting of the microorganisms and their associated biological films (with anti-fouling properties), insects and rodents that attack wood, without affecting other species, humans included. Specific attention is given also to the wood-coating compatibility issues that significantly influence the performance of the coating, since neither effective wood surface pre-treatment, nor coupling alone may be enough to create an inter-phase able to strongly bond the coating to the wooden substrate. On the other hand, high-performance coatings are the result of extensive research and high-tech manufacture, with increased financial efforts, while the consumers' demands go for low costs involved. Not in the least, the use of nanotechnology and nanomaterials raised some health risk concerns, as in the case of nanoparticles environmental release from nano-structured coatings deposited onto wood furniture, siding, etc. All of these challenges require a complex, interdisciplinary approach, where solutions from different areas can be wisely combined in order to reach the main goal - wood enhanced durability, while employing stable, efficient, environmentally friendly, biocompatible and/or biodegradable, yet cost effective, wood coatings. 


\section{ACKNOWLEDGEMENTS}

This work was supported by the Romanian National Authority for Scientific Research and Innovation CCCDI-UEFISCDI, project number ERANET-ERA IB-16-040ProWood, within PNCDI III.

\section{REFERENCES CITED}

Alfredsen, G., Eikenes, M., Solheim, H., and Militz, H. (2004). "Screening of chitosan against wood deteriorating fungi," Scand. J. Forest Res. 19(5), 4-13. DOI: 10.1080/02827580410017807

Andrady, A. L., Hamid, H., and Torikai, A. (2011). 'Effects of solar UV and climate change on materials," Photochem. Photobiol. Sci.10, 292-300. DOI: 10.1039/c0pp90038a

Andrady, A. L., Torikai, A., Redhwi, H. H., Pandey, K. K., and Gies, P. (2015). "Consequences of stratospheric ozone depletion and climate change on the use of materials," Photochem. Photobiol. Sci. 14(2), 170-184. DOI: 10.1039/C4PP90038C

Bardage, S. L. (1998). "Susceptibility of painted wood to Aureobasidium pullulans: Fungal stain and growth patterns," Holz Roh-Werkst.56, 359-364. DOI: $10.1007 / \mathrm{s} 001070050333$

Bazyar, B. (2012). "Decay resistance and physical properties of oil heat treated aspen wood," BioResources 7(1), 696-705. DOI: 10.15376/biores.7.1.0696-0705

Breuil, C. (1998). "Wood as a nutritional resource for staining fungi," in: Proceedings of Biology and Prevention of Sapstain, Whistler, Canada, Forest Products Society, Madison, WI, USA, pp. 1-7.

Brischke, C., and Melcher, E. (2015). "Performance of wax-impregnated timber out of ground contact: results from long-term field testing," Wood Sci. Technol. 49(1), 189204. DOI: $10.1007 / \mathrm{s} 00226-014-0692-6$

Brock, T., Groteklaes, M., and Mischke, P. (2010). European Coatings Handbook, Second Edition, Vincentz Verlag, Hannover, Germany, pp. 432.

Brown, H. L., and Bruce, A. (1999). "Assessment of the biocontrol potential of a Trichoderma viride isolate. Part I: Establishment of field and fungal cellar trials," Int. Biodeter. Biodegrad. 44(4), 219-223. DOI: 10.1016/S0964-8305(99)00082-7

Bruce, A., and Highley, T. L. (1991). "Control of growth of wood decay basidiomycetes by Trichoderma spp. and other potentially antagonistic fungi," For. Prod. J. 41, 6367.

Bruce, A., Smith, G. M., King, B., Hainey, S. D., and Evans, P. D. (1991). "Soil-bed decay studies of softwood pole segments treated with CCA by sap-displacement. 1. Evaluation of soil bed exposure and assessment of soft rot decay," Wood Protection $1(1), 1-7$.

Bruce, A. (1997). "Biological control of wood decay," in: Forest Products Biotechnology, A. Bruce, and J. W. Palfreyman (eds.), Taylor and Francis, London, pp. 251-266. 
Bruce, A., Stewart, D., Verrall, S., and Wheatley, R. E., (2003). "Effect of volatiles from bacteria and yeast on the growth and pigmentation of sapstain fungi," Int. Biodeterior. Biodegrad. 51(2), 101-108. DOI: 10.1016/S0964-8305(02)00088-4

Bulian, F., and Graystone J. A. (2009). Industrial Wood Coatings. Theory and Practice, First Edition, Elsevier, Amsterdam, pp. 135.

Canessa, E.A., and Morrell, J. J. (1997). "Biological control of wood decay fungi - I. Effects of exogenous carbon on effectiveness," Mater. Organismen 31(3), 167-182.

Carrillo-Parra, A., Hapla, F., Mai, C., and Garza-Ocañas, F. (2011). "Durability of wood of Prosopis laevigata and the effect of its extractives on wood-decaying fungus," Madera Bosques 17(1), 7-21. DOI: 10.21829/myb.2011.1711151

Carter, F. L., Garlo, A. M., and Stanley, J. B. (1978). "Termiticidal components of wood extracts: 7-methyl-juglone from Diospyros virginiana," J. Agric. Food Chem. 26(4), 869-873. DOI: $10.1021 / \mathrm{jf60218a018}$

Chang, S. T., Wang, J.-H., Wu, C. L., Chen, P. F., and Kuo, Y. H. (2000). "Comparison of the antifungal activity of cadinane skeletal sesquiterpenoid from Taiwania (Tawania crypromerioides Hayara) heartwood," Holzforschung 54(3), 241-245. DOI: 10.1515/HF.2000.041

Chang, H.-T., Cheng, Y.-H., Wu, C.-L., Chang, S.-T., Chang, T.-T., and Su, Y.-C. (2008). "Antifungal activity of essential oil and its constituents from Calocedrus macrolepis var. formosana Florin leaf against plant pathogenic fungi," Bioresour. Technol. 99(14), 6266-6270. DOI: 10.1016/j.biortech.2007.12.005

Chen, K., Ohmura, W., Doi, S., and Aoyama, M. (2004). "Termite feeding deterrent from Japanese larch wood," Bioresour. Technol. 95(2), 129-134. DOI: 10.1016/j.biortech.2004.02.014

Chi, Z., Wang, F., Chi, Z., Yue, L., Liu, G., and Zhang, T. (2009). "Bioproducts from Aureobasidium pullulans, a biotechnologically important yeast," Appl. Microbiol. Biotechnol. 82(5), 793-804. DOI: 10.1007/s00253-009-1882-2

Chirkova, J., Andersone, I., Irbe, I., Spince, B., and Andersons, B. (2011). "Lignins as agents for bio-protection of wood," Holzforschung 65(4), 497-502. DOI: 10.1515/hf.2011.092

Clausen, C. A., and Yang, V. (2007). "Protecting wood from mould, decay, and termites with multi-component biocide systems," Int. Biodeter. Biodegrad. 59, 20-24. DOI: 10.1016/j.ibiod.2005.07.005

Coatings World (2016). "Wood Coatings Market," (https://www.coatingsworld.com/issues/2016-02-01/view_features/wood-coatingsmarket), Accessed 25 January 2019.

Cogulet, A., Blanchet, P., and Landry, V. (2018). “The multifactorial aspect of wood weathering: A review based on a holistic approach of wood degradation protected by clear coating," BioResources 13, 2116-2138. DOI: 10.15376/biores.13.1.2116-2138

Cook, R. J., and Baker, K. R. (1983). The Nature and Practice of Biological Control of Plant Pathogens, American Phytopathology Society, St. Paul, MN, pp. 539.

Croitoru, C., Patachia, S., and Lunguleasa, A. (2015). "A mild method of wood impregnation with biopolymers and resins using 1-ethyl-3-methylimidazolium chloride as carrier," Chem. Eng. Res. Des. 93, 257-268. DOI:

10.1016/j.cherd.2014.04.031

Daniliuc, A., Deppe, B., Deppe, O., Friebel, S., Kruse, D., and Philipp, C. (2012). "New trends in wood coatings and fire retardants. Biobased monomers and high performance coatings," EC Journal 7(8), 20-25. 
Demirel, G. K., Temiz, A., Demirel, S., Jebrane, M., Terziev, N., Gezer, E. D., et al. (2016). "Dimensional stability and mechanical properties of epoxidized vegetable oils as wood preservatives," in: Proceedings COST Action FP1407, $2^{\text {nd }}$ Conference on Innovative Production Technologies and Increased Wood Products Recycling and Reuse, A. Kutnar, M. Schwarzkopf, M. Burnard, V. Sebera, and E. Troppova (eds.), 29-30 ${ }^{\text {th }}$ September 2016, Brno, Czech Republic, pp. 49-50.

Eikenes, M., Alfredsen, G., Christensen, B., Militz, H., and Solheim, H. (2005). "Comparison of chitosan with different molecular weights as possible wood preservatives," J. Wood Sci. 51(4), 387-394. DOI: 10.1007/s10086-004-0659-6

Ejechi, B. O. (1997). "Biological control of wood decay in an open tropical environment with Penicillium spp. and Trichoderma viride," Int. Biodeterior. Biodegrad. 39(4), 295-299. DOI: 10.1016/S0964-8305(97)00023-1

Ejechi, B. O., and Akpomedaye, D. E. (1998). "The hurdle effect of ureolytic Proteus sp. activity and Trichoderma viride culture filtrate on growth and wood deteriorating activities of four fungi," Int. Biodeterior. Biodegrad. 41(2), 153-155. DOI: 10.1016/S0964-8305(97)00083-8

El-Fouly, M. Z., Shahin, A. A.-F. M., and El-Bialy, H. A.-A. (2011). "Biological control of sapstain fungi in Egyptian wood stores and infected trees," Ann. Microbiol. 61(4), 789-799. DOI: 10.1007/s13213-011-0197-6

El-Gamal, R., Nikolaivits, E., Zervakis, G. I., Abdel-Maksoud, G., Topakas, E., and Christakopoulos, P. (2016). "The use of chitosan in protecting wood artifacts from damage by mold fungi," Electron. J. Biotechnol. 24, 70-78. DOI: 10.1016/j.ejbt.2016.10.006

Esteves, B. M., and Pereira, H. M. (2009). "Wood modification by heat treatment: A review," BioResources 4(1), 370-404.

Evans, J. A., Eyre, C. A., Rogers, H. J., Boddy, L., and Müller, C. T. (2008). "Changes in volatile production during interspecific interactions between four wood rotting fungi growing in artificial media," Fungal Ecol. 1(2), 57-68. DOI:

10.1016/j.funeco.2008.06.001

Fengel, D. (1991). "Aging and fossilization of wood and its components," Wood Sci. Technol. 25, 153-177. DOI: 10.1007/BF00223468

Fengel, D., and Wegener, G. (2003). Wood-Chemistry, Ultrastructure, Reactions, Third Edition, Verlag Kessel, Remagen, Germany, 613 pp.

Fratzl, P., and Weinkamer, R. (2007). "Nature's hierarchical materials," Prog. Mat. Sci. 52, 1263-1334. DOI: 10.1016/j.pmatsci.2007.06.001

Ganapaty, S., Thomas, P. S., Fotso, S., and Laatsch, H. (2004). "Antitermitic quinones from Disopyros sylvatica," Phytochem. 65(9), 1265-1271. DOI: 10.1016/j.phytochem.2004.03.011

Garcia, H., Ferreira, R., Petkovic, M., Ferguson, J. L., Leitao, M. C., Gunaratne, H.Q.N., Seddon, K. R., Rebelo, L. P. N., and Pereira, C. S. (2010). "Dissolution of cork biopolymers in biocompatible ionic liquids," Green Chem. 12(3), 367-369. DOI: $10.1039 / \mathrm{b} 922553 \mathrm{f}$

Gérardin, P. (2016). "New alternatives for wood preservation based on thermal and chemical modification of wood - A review," Ann. For. Sci. 73(3), 559-570. DOI: 10.1007/s13595-015-0531-4

González-Laredo, R. F., Rosales-Castro, M., Rocha-Guzmán, N. E., Gallegos-Infante, J. A., Moreno-Jiménez, M. R., and Karchesy, J. J. (2015). "Wood preservation using natural products," Madera Bosques 21, 63-76. DOI: 10.21829/myb.2015.210427 
Griffini, G., Passoni, V., Suriano, R., Levi, M., and Turri, S. (2015). "Polyurethane coatings based on chemically unmodified fractioned lignin," ACS Sustain. Chem. Eng. 3(6), 1145-1154. DOI: 10.1021/acssuschemeng.5b00073

Harman, G. E., Howell, C. R., Viterbo, A., Chet, I., and Lorito, M. (2004). “Trichoderma species - Opportunistic avirulent plant symbionts," Nat. Rev. Microbiol. 2(1), 43-56. DOI: $10.1038 / \mathrm{nrmicro} 797$

Held, B. W., Thwaites, J. M., Farrell, R. L., and Blanchette, R. A. (2003). “Albino strains of Ophiostoma species for biological control of sapstaining fungi," Holzforschung 57(3), 237-242. DOI: 10.1515/HF.2003.036

Herrera, R., Gordobil, O., Llano-Ponte, R., and Labidi, J. (2016). "Esterified lignin as hydrophobic agent for use on wood products," in: Proceedings of the COST Action FP1407, $2^{\text {nd }}$ Conference, Innovative Production Technologies and Increased Wood Products Recycling and Reuse, 29-30 September 2016, Brno, Czech Republic, p. 79.

Humar, M., and Lesar, B. (2013). "Efficacy of linseed- and tung-oil-treated wood against wood-decay fungi and water uptake," Int. Biodeter. Biodegrad. 85, 223-227. DOI: 10.1016/j.ibiod.2013.07.011

Humphries, S. N., Bruce, A., and Wheatley, R. E. (2002). "The effect of Trichoderma volatiles on protein synthesis in Serpula lacrymans," FEMS Microbiol. Lett. 210(2), 215-219. DOI: 10.1111/j.1574-6968.2002.tb11183.x

Hyvönen, A., Piltonen, P., and Niinimäki, J. (2006). "Tall oil/water - emulsions as water repellents for Scots pine sapwood," Holz Roh-Werkst. 64(1), 68-73. DOI: 10.1007/s00107-005-0040-5

Hyvönen, A., Nelo, M., Piltonen, P., Hormi, O., and Niinimäki, J. (2007a). "Using iron catalyst to enhance the drying properties of crude tall oil-based wood preservative," Holz Roh-Werkst. 65(2), 105-111. DOI: 10.1007/s00107-006-0119-7

Hyvönen, A., Nelo, M., Piltonen, P., and Niinimäki, J. (2007b). "Using the emulsion technique and an iron catalyst to enhance the wood protection properties of tall oil," Holz Roh-Werkst. 65(3), 247-249. DOI: 10.1007/s00107-006-0156-2

Islam, M., Shams, I., Ilias, G. N. M., and Hannan, O. (2009). "Protective antifungal effect of neem (Azadirachta indica) extracts on mango (Mangifera indica) and rain tree (Albizia saman) wood," Int. Biodeter. Biodegrad. 63(2), 241-243. DOI: 10.1016/j.ibiod.2008.07.010

Kartal, S. N., Hwang, W.-J., Imamura, Y., and Sekine, Y. (2006). "Effect of essential oil compounds and plant extracts on decay and termite resistance of wood," Holz RohWerkst. 64(6), 455-461. DOI: 10.1007/s00107-006-0098-8

Kawaguchi, H., Kim, M., Ishida, M., Ahn, Y. J., Yamamoto, T., Yamaoka, R., Kozuka, M., Goto, K., and Takahashi, S. (1989). "Several antifeedants from Phellodendron amurense against Reticulitermes speratus," Agric. Biol. Chem. 53(10), 2635-2640. DOI: $10.1271 / \mathrm{bbb} 1961.53 .2635$

Khalil, H.P.S.A., Kong, N. H., Ahmad, M. N., Bhat, A.H., Jawaid, M., and Jumat, S. (2009). "Selective solvent extraction of the bark of Rhizophora apiculata as antitermite agent against Coptotermes gestroi, ”J. Wood Chem. Technol. 29(4), 286-304. DOI: 10.1080/02773810903165663

Kirker, G., and Winandy, J. (2014). "Above ground deterioration of wood and woodbased materials," in: Deterioration and Protection of Sustainable Biomaterials, T. P. Schultz, B. Goodell, and D. D. Nicholas (eds.), ACS Symposium Series, American Chemical Society, Washington, DC, 113-129. 
Koski, A. (2008). Applicability of Crude Tall Oil for Wood Protection, Academic dissertation, Faculty of Technology, University of Oulu, Acta Univ. Oul. C 293, Oulu University Press, Oulu, Finland.

Kranitz, K., Sonderegger, W., Bues, C.-T., and Niemz, P. (2016). "Effects of aging on wood: A literature review," Wood Sci. Technol. 50, 7-22. DOI: 10.1007/s00226-0150766-0

Laflamme, P., Benhamou, N., Bussires, G., and Dessureault, M. (2000). "Differential effect of chitosan on root rot fungal pathogens in forest nurseries," Can. J. Bot. 77(10), 1460-1468. DOI: 10.1139/cjb-77-10-1460

Laks, P., Peggy, A., and Hemingway, R. W. (1988). "Flavanoid biocides: Wood preservatives based on condensed tannins," Holzforschung 42(5), 299-306. DOI: 10.1515/hfsg.1988.42.5.299

Laks, P. (1991). Method for Treating Wood Against Fungal Attack, U.S. Patent No. 4988 545.

Larnøy, E., Eikenes, M., and Militz, H. (2005). "Uptake of chitosan based impregnation solutions with varying viscosities in four different European wood species," Holz Roh-Werkst. 63(6), 456-462. DOI: 10.1007/s00107-005-0014-7

Lin, C.Y., Wu, C. L., and Chang, S. T. (2007). "Evaluating the potency of cinnamaldehyde as a natural wood preservative," in: Proceedings of the $48^{\text {th }}$ Annual Meeting of the International Research Group on Wood Protection, 20-24 May 2007, Jackson Lake, Wyoming, USA, Doc. no. IRG/WP 07-30444.

Liu, C., Wang, S., Shi, J., and Wang, C. (2011). "Fabrication of superhydrophobic wood surfaces via a solution-immersion process," Appl. Surf. Sci. 258(2), 761-765. DOI: 10.1016/j.apsusc.2011.08.077

Lotz, W. R. (1993). "Wood preservation systems including halogenated tannin extracts," U.S. Patent No. 5270083.

Lyon, F., Thevenon, M. F., Imamura, Y., Gril, J., and Pizzi, A. (2007). "Development of boron/linseed oil combination treatment as a low-toxic wood protection: evaluation of boron fixation and resistance to termites according to Japanese and European standards," in: Proceedings of the $48^{\text {th }}$ Annual Meeting of the International Research Group on Wood Protection, 20-24 May 2007, Jackson Lake, Wyoming, USA, Doc. no. IRG/WP 07-30448.

Lyon, F., Thevenon, M. F., Pizzi, A., and Gril, J. (2009). "Resistance to decay fungi of ammonium borate oleate treated wood," in Proceedings of the $40^{\text {th }}$ Annual Meeting of the International Research Group on Wood Protection, 24-28 May 2009, Beijing, China, 2009, Doc. No. IRG/WP 09-30505.

Macias, F. A., Torres, A., Maya, C.C., and Fernandez, B. (2005). "Natural biocides from citrus waste as new wood preservatives," in: Proceedings of Fourth World Congress on Allelopathy, 21-26 August 2005, Charles Sturt University, Wagga Wagga, Australia.

Mai, C., Kües, U., and Militz, H. (2004). "Biotechnology in the wood industry," Appl. Microbiol. Biotechnol. 63, 477-494. DOI: 10.1007/s00253-003-1411-7

Maoz, M., Weitz, I., Blumenfeld, M., Freitag, C., and Morrell, J. J. (2007). “Antifungal activity of plant derived extracts against G. trabeum," in: Proceedings of the $38^{\text {th }}$ Annual Meeting of the International Research Group on Wood Protection, 20-24 May 2007, Wyoming, USA, Doc. no. IRG/WP 07-30433.

Matuana, L. M., and Stark, N. M. (2015). "The use of wood fibers as reinforcements in composites," in: Biofiber Reinforcement in Composite Materials, O. Faruk, and M. 
Sain (eds.), Woodhead Publishing, Elsevier, 648-688. DOI:

10.1533/9781782421276.5.648

Moita, C., Feio, S. S., Nunes, L., Curto, M. J. M., and Roseiro, J. C. (2005).

"Optimisation of physical factors on the production of active metabolites by Bacillus subtilis 355 against wood surface contaminant fungi," Int. Biodeterior. Biodegrad. 55(4), 261-269. DOI: 10.1016/j.ibiod.2005.02.003

Morimoto, M., Fukumoto, H., Hiratani, M., Chavasir, W., and Komai, K. (2006). "Insect antifeedants, pterocarpans and pterocarpol in heartwood of Pterocarpus macrocarpus," Kruz. Biosci. Biotechnol. Biochem. 70(8), 1864-1868. DOI: 10.1271/bbb.60017

Morin, C., Tanguay, P., Breuil, C., Yang, D.-Q., and Bernier, L. (2006). "Bioprotection of spruce logs against sapstain using an albino strain of Ceratocystis resinifera," Phytopathology 96(5), 526-533. DOI: 10.1094/PHYTO-96-0526

Morris, P. I., and Stirling, R. (2012). "Western red cedar extractives associated with durability in ground contact," Wood Sci. Technol. 46(5), 991-1002. DOI: 10.1007/s00226-011-0459-2

Mubofu, E. B., and Mgaya, J. E. (2018). "Chemical valorization of cashew nut shell waste,” Top. Curr. Chem. (Z) 376(8), 15 pages. DOI: 10.1007/s41061-017-0177-9

Nakamura, C. E., and Whited, G. M. (2003). "Metabolic engineering for the microbial production of 1,3 -propanediol," Curr. Opin. Biotechnol. 14(5), 454-459. DOI 10.1016/j.copbio.2003.08.005

Nakayama, F. S., and Osbrink, W. L. (2010). "Evaluation of kukui oil (Aleurites moluccana) for controlling termites," Ind. Crops Prod. 31(2), 312-315. DOI: 10.1016/j.indcrop.2009.11.009

Nascimento, M. S., Santana, A.L.B.D., Maranhão, C. A., Oliveira, L. S., and Bieber, L. (2013). "Phenolic extractives and natural resistance of wood," in: Biodegradation Life of Science, Chamy, R., and Rosenkranz, F. (eds.), InTech, Croatia, 349-370.

Németh, R., Tsalagkas, D., and Bak, M. (2015). "Effect of soil contact on the modulus of elasticity of beeswax-impregnated wood," BioResources 10(1), 1574-1586. DOI: 10.15376/biores.10.1.1574-1586

Nowrouzi, Z., Mohebby, B., and Younesi, H. (2016). "Treatment of fir wood with chitosan and PEG," J. Forestry Res. 27(4), 959-966. DOI: 10.1007/s11676-015-0174-1

Ohmura, W., Doi, S., Aoyama, M., and Ohara, S. (2000). "Antifeedant activity of flavonoids and related compounds against the subterranean termite Coptotermes formosanus Shiraki," J. Wood Sci. 46(2), 149-153. DOI: 10.1007/BF00777362

Olsson, S. (2012). Enhancing UV-Protection of Clear Coated Wood by Utilizing Reactive $U V$-Absorber and Epoxy Functionalized Soybean Oil, Licentiate thesis, Kungliga Tekniska Högskolan, Stockholm, Sweden.

Olsson, S. K., Matsunaga, H., Kataoka, Y., Johansson, M., Matsumura, J., Westin, M., and Östmark, E. (2015). "A SEM study on the use of epoxy functional vegetable oil and reactive UV-absorber as UV-protecting pretreatment for wood," Polym. Degrad. Stabil. 113, 40-45. DOI: 10.1016/j.polymdegradstab.2015.01.005

Ozgenc, O., Okan, O. T., Y1ld1z, U. C., and Deniz, I. (2013). "Wood surface protection against artificial weathering with vegetable seed oils," BioResources 8(4), 6242-6262. DOI: $10.15376 /$ biores.8.4.6242-6262

Palfreyman, J. W., White, N. A., Buultjens, T. E. J., and Glancy, H. (1995). “The impact of current research on the treatment of infestations by the dry rot organism Serpula 
lacrymans," Int. Biodeter. Biodegrad. 35(4), 369-395. DOI: 10.1016/09648305(95)00064-3

Panov, D., and Terziev, N. (2015). "Durability of epoxi-oil modified and alkoxylane treated wood in field testing," BioResources 10(2), 2479-2491. DOI:

10.15376/biores.10.2.2479-2491

Patachia, S., Croitoru, C., and Friedrich, C. (2012). "Effect of UV exposure on the surface chemistry of wood veneers treated with ionic liquids," Appl. Surf. Sci. 258(18), 67236729. DOI: 10.1016/j.apsusc.2011.12.050

Phillips-Laing, E. M., Staines, H. J., and Palfreyman, J. W. (2003). "The isolation of specific biocontrol agents for the dry rot fungus Serpula lacrymans," Holzforschung 57(6), 574-578. DOI: 10.1515/HF.2003.086

Pichelin, F., Kamoun, C., and Pizzi, A. (1997). "Hexamine hardener behaviour: Effects on wood glueing, tannin and other wood adhesives," Holz Roh-Werkst. 57(5), 305317. DOI: $10.1007 / \mathrm{s} 001070050349$

Pichelin, F., Nakatani, M., Pizzi, A., Wieland, S., Despres, A., and Rigolet, S. (2006). "Thick wood panels bonded industrially with formaldehyde free tannin adhesives," For. Prod. J. 56(5), 31-36.

Pizzi, A. (1994). "Tannin-based wood adhesives," in: Advanced Wood Adhesives and Technology, A. Pizzi (ed.), Marcel Dekker Inc., New York, pp. 149-217.

Rao, B. S., and Palanisamy, A. (2013). "Synthesis of bio based low temperature curable liquid epoxy, benzoxazine monomer system from cardanol: Thermal and viscoelastic properties," Eur. Polym. J. 49(8), 2365-2376. DOI: 10.1016/j.eurpolymj.2013.05.029

Reinprecht, L. (2010). "Fungicides for wood protection - World viewpoint and evaluation/ testing in Slovakia," in: Fungicides, O. Carisse (ed.), InTech, Rijeka, Croatia, pp. 95-122.

Reyes-Chilpa, R., Gomez-Garibay, F., Moreno-Torres, G., Jimenez-Estrada, M., and Quiroz Vaásquez, R. I. (1998). "Flavonoids and isoflavonoids with antifungal properties from Platymiscium yucatanum heartwood," Holzforschung 52(5), 459-462. DOI: $10.1515 / \mathrm{hfsg} .1998 .52 .5 .459$

Rodrigues, A. M. S., Stien, D., Eparvier, V., Espindola, L. S., Beauchêne, J., Amusant, N., Leménager, N., Baudasse, C., and Raguin, L. (2012). "The wood preservative potential of long-lasting Amazonian wood extracts," Int. Biodeter. Biodegrad. 75, 146-149. DOI: 10.1016/j.ibiod.2012.03.014

Roos, K. D., and Archer, K. J. (2004). "Reactive oil/copper preservative systems for wood products," U.S. Patent No. 6686056.

Roşu, D., Bodîrlău, R., Teacă, C.-A., Roşu, L., and Varganici, C. D. (2016). "Epoxy and succinic anhydride functionalized soybean oil for wood protection against UV light action," J. Clean. Prod.112, 1175-1183. DOI: 10.1016/j.jclepro.2015.07.092

Roşu, L., Varganici, C. D., Mustață, F., Rusu, T., Roşu, D., Roşca, I., Tudorachi, N., and Teacă, C.-A. (2018). "Enhancing the thermal and fungal resistance of wood treated with natural and synthetic derived epoxy resins," ACS Sustain. Chem. Eng. 6, 54705478. DOI: 10.1021/acssuschemeng.8b00331

Rowell, R. M., Pettersen, R., and Tshabalala, M. A. (2013). "Cell wall chemistry," in: Handbook of Wood Chemistry and Wood Composites, R. Rowell (ed.), Second Edition, Boca Raton, FL, CRC Press, USA, pp. 33-72.

Sablik, P., Giagli, K., Paril, P., Baar, J., and Rademacher, P. (2016). "Impact of extractive chemical compounds from durable wood species on fungal decay after impregnation 
of nondurable wood species," Eur. J. Wood Prod. 74(2), 231-236. DOI:

10.1007/s00107-015-0984-Z

Sailer, M. F., van Nieuwenhuijzen, E. J., and Knol, W. (2010). "Forming of a functional biofilm on wood surfaces," Ecol. Eng. 36(2), 163-167. DOI:

10.1016/j.ecoleng.2009.02.004

Santana, A. L. B. D., Maranhão, C. A., Santos, J. C., Cunha, F. M., Conceição, G. M., Bieber, L.W., and Nascimento, M. S. (2010). "Antitermitic activity of extractives from three Brazilian hardwoods against Nasutitermes corniger," Int. Biodeter. Biodegrad. 64(1), 7-12. DOI: 10.1016/j.ibiod.2009.07.009

Schaller, C., and Rogez, D. (2007). "New approaches in wood coating stabilization," $J$. Coat. Technol. Res. 4(4), 401-409. DOI: 10.1007/s11998-007-9049-5

Scheffer, T. C. (1971).” A climate index for estimating potential for decay in wood structures above ground," For. Prod. J. 21(10), 25-31.

Scheffer, T. C., and Morrell, J. J. (1998). Natural Durability of Wood: A Worldwide Checklist of Species, Forest Research Laboratory, Oregon State University, Research Contribution 22, pp. 58.

Schoeman, M. W., Webber, J. F., and Dickinson, D. J. (1994). "Chainsaw application of Trichoderma harzianum Rifai to reduce fungal deterioration of freshly felled pine logs," Mater. Organismen 28(4), 243-250.

Schoeman, M., and Dickinson, D. (1997). "Growth of Aureobasidium pullulans on lignin breakdown products at weathered wood surfaces," Mycologist 11, 168-172. DOI: 10.1016/S0269-915X(97)80095-X

Schultz, T. P., Harms, W. B., Fisher, T. H., McMurtrey, K. D., Minn, J., and Nicholas, D. D. (1995). "Durability of angiosperm heartwood: the important of extractives," Holzforschung 49(1), 29-34. DOI: 10.1515/hfsg.1995.49.1.29

Schultz, T. P., and Nicholas, D. D. (2002). "Development of environmentally-benign wood preservatives based on the combination of organic biocides with antioxidants and metal chelators," Phytochem. 61(5), 555-560. DOI: 10.1016/S00319422(02)00267-4

Score, A., and Palfreyman, J. W. (1994). "Biological control of the dry rot fungus Serpula lacrymans and Trichoderma spp. effects of media constraints on interaction and growth rates," Int. Biodeter. Biodegrad. 33(2), 115-128. DOI: 10.1016/09648305(94)90031-0

Score, A. J., Bruce, A., King, B., and Palfreyman, J. M. (1998). "The biological control of Serpula lacrymans by Trichoderma species," Holzforschung 52(2), 124-132.

Sen, S., and Yalçin, M. (2010). "Activity of commercial still waters from volatile oils production against wood decay fungi," Maderas-Cienc. Tecnol. 12(2), 127-133.

Singh, T., and Chittenden, C. (2008). "In-vitro antifungal activity of chill extracts in combination with Lactobacillus casei against common sapstain fungi," Int. Biodeterior. Biodegrad. 62(4), 364-367. DOI: 10.1016/j.ibiod.2007.10.009

Singh, T., and Singh, A. P. (2010). "Natural compounds: A review of their use for wood protection," in: Proceedings of the $41^{\text {th }}$ Annual Meeting of the International Research Group on Wood Protection, 9-13 May 2010, Biarritz, France, Doc. No. IRG/WP 1030545.

Singh, T., and Singh, A. P. (2012). "A review on natural products as wood protectant," Wood Sci. Technol. 46, 851-870. DOI: 10.1007/s00226-011-0448-5 
Stasiewicz, M., Fojutowski, A., Kropacz, A., and Pernak, J. (2008). "1-Alkoxymethyl-Xdimethylaminopyridinium-base ionic liquids in wood preservation," Holzforschung 62(3), 309-317. DOI: 10.1515/HF.2008.028

Stenbæk, J. (2015). Bio-sustainable Control of the Blue Stain Fungi Aureobasidium pullulans on Exterior Wood Coatings, PhD Dissertation, Faculty of Science University of Copenhagen, Denmark.

Sundararaj, R., Shanbhag, R. R., Nagaveni, H. C., and Vijayalakshmi, G. (2015). "Natural durability of timbers under Indian environmental conditions - An overview," Int. Biodeter. Biodegrad. 103, 196-214. DOI: 10.1016/j.ibiod.2015.04.026

Susi, P., Aktuganov, G., Himanen, J., and Korpela, T. (2011). "Biological control of wood decay against fungal infection," J. Environ. Manage. 92, 1681-1689. DOI: 10.1016/j.jenvman.2011.03.004

Syofuna, A., Banana, A.Y., and Nakabonge, G. (2012). "Efficiency of natural wood extractives as wood preservatives against termite attack," Maderas-Cienc. Tecnol. 14(2), 155-163. DOI: 10.4067/S0718-221X2012000200003

Tan, S., and Chow, W. (2010). "Biobased epoxidized vegetable oils and its greener epoxy blends: A review," Polym. Plast. Technol. 49(15), 1581-1590. DOI: 10.1080/03602559.2010.512338

Tascioglu, C., Yalcin, M., Troya, T., and Sivrikaya, H. (2012). "Termiticidal properties of some wood and bark extracts used as wood preservatives," BioResources 7(3), 2960-2969. DOI: 10.15376/biores.7.3.2960-2969

Tascioglu, C., Yalcin, M., Sen, S., and Akcay, C. (2013). “Antifungal properties of some plant extracts used as wood preservatives," Int. Biodeter. Biodegrad. 85(1), 23-28. DOI: 10.1016/j.ibiod.2013.06.004

Taylor, A. M., Gartner, B. L., and Morrell, J. J. (2006). "Effects of heartwood extractive fractions of Thuja plicata and Chamaecyparis nootkatensison wood degradation by termites or fungi," J. Wood Sci. 52(2), 147-153. DOI: 10.1007/s10086-005-0743-6

Teacă, C.-A., Roşu, D., Bodîrlău, R., and Roşu, L. (2013). "Structural changes in wood under artificial UV light irradiation determined by FTIR spectroscopy and color measurements - A brief review," BioResources 8(1), 1478-1507. DOI: 10.15376/biores.8.1.1478-1507

Teacă, C.-A., and Bodîrlău, R. (2016). "Photochemical behavior of wood based materials," in: Photochemical Behavior of Multicomponent Polymeric-based Materials, Roşu, D., and Visakh, P. M. (eds.), Advanced Structured Materials 26, Springer International Publishing Switzerland, 91-107.

Teacă, C.-A., Roşu, L., Marlică, E., Roşu, D., Rusu, T., Mustaţă, F., and Varganici, C.-D. (2018). "Investigation of wood properties after treatment by impregnation with natural vegetable oils," paper presented at the $12^{\text {th }}$ European Symposium on Thermal Analysis and Calorimetry (ESTAC12), August 27-30, 2018, Braşov, Romania, Book of abstracts, pp. 524.

Temiz, A., Terziev, N., Eikenes, M., and Hafren, J. (2007). "Effect of accelerated weathering on surface chemistry of modified wood," Appl. Surf. Sci. 253(12), 53555362. DOI: $10.1016 /$ j.apsusc.2006.12.005

Thanamongkollit, N. (2008). Modification of Tung Oil for Bio-Based Coating, Master's Thesis, University of Akron, Ohio, USA.

Thevenon, M. F., Tondi, G., and Pizzi, A. (2009). "High performance tannin resin-boron wood preservatives for outdoor end-uses," Eur. J. Wood Prod. 67(1), 89-93. DOI: 10.1007/s00107-008-0290-0 
Tondi, G., Zhao, W., Pizzi, A., Du, G., Fierro, V., and Celzard, A. (2009a). "Tanninbased rigid foams: A survey of chemical and physical properties," Bioresour Technol. 100(21), 5162-5169. DOI: 10.1016/j.biortech.2009.05.055

Tondi, G., Oo, C. W., Pizzi, A., Trosa, A., and Thevenon, M. F. (2009b). "Metal absorption of tannin based rigid foams," Ind. Crop. Prod. 29(2), 336-340. DOI: 10.1016/j.indcrop.2008.06.006

Tondi, G., Wieland, S., Wimmer, T., Thevenon, M. F., Pizzi, A., and Petutschnigg, A. (2012). "Tannin-boron preservatives for wood buildings: Mechanical and fire properties," Eur. J. Wood Prod. 70(5), 689-696. DOI: 10.1007/s00107-012-0603-1

Treu, A., Militz, H., and Breyne, S. (2001). "Royal-treatment - Scientific background and practical application," in: Proceedings of COST Action E22 Conference: Environmental Optimization of Wood Protection, 8-10 November 2001, Reinbek, Germany, pp. 1-8.

Unger, A., Schniewind, A. P., and Unger, W. (2001). "Biological deterioration of wood," in: Conservation of Wood Artifacts. A Handbook, A. Unger, A. P. Schniewind, and W. Unger (eds.), Springer-Verlag, Berlin, Heidelberg, Germany, pp. 51-141. DOI: 10.1007/978-3-662-06398-9_6

van Eckeveld, A., Homan, W. J., and Militz, H. (2001). "Increasing the water repellency of Scots pine sapwood by impregnation with undiluted linseed oil, wood oil, cocos oil and tall oil," Holzforschung 53(6), 113-115.

van Nieuwenhuijzen, E. J., Sailer, M. F., Gobakkend, L. R., Adan, O.C.G., Punt, P. J., and Samson, R. A. (2015). "Detection of outdoor mould staining as biofinish on oil treated wood," Int. Biodegr. Biodeterior. 105, 215-227. DOI: 10.1016/j.ibiod.2015.09.001

van Nieuwenhuijzen, E. J., Houbraken, J. A. M. P., Meijer, M., Adan, O. C. G., and Samson, R. A. (2016). "Aureobasidium melanogenum: A native of dark biofinishes on oil treated wood," Antonie van Leeuwenhoek 109(5), 661-683. DOI: 10.1007/s10482-016-0668-7

Vanneste, J. L., Hill, R. A., Kay, S. J., Farrell, R. L., and Holland, P. T. (2002). "Biological control of sapstain fungi with natural products and biological control agents: A review of the work carried out in New Zealand," Mycol. Res. 106(2), 228232. DOI: $10.1017 / \mathrm{S} 0953756201005020$

Vartanian, E., Barres, O., and Roque, C. (2015). "FTIR spectroscopy of woods: A new approach to study the weathering of the carving face of a sculpture," Spectrochim. Acta Part A 136, 1255-1259. DOI:10.1016/j.saa.2014.10.011

Verma, M., Brar, S. K., Tyagi, R. D., Surampalli, R.Y., and Valero J. R. (2007). "Antagonistic fungi, Trichoderma spp.: Panoply of biological control. Review," Biochem. Eng. J. 37(1), 1-20. DOI:10.1016/j.bej.2007.05.012

Watanabe, Y., Mihara, R., Mitsunaga, T., and Yoshimura, T. (2005). "Termite repellent sesquiterpenoids from Callitris glaucophylla heartwood," J. Wood Sci. 51(5), 514519. DOI:10.1007/s10086-004-0683-6

Wheatley, R. E., Hackett, C., Bruce, A., and Kundzewicz, A. (1997). "Effect of substrate composition on production of volatile organic compounds from Trichoderma spp. Inhibitory to wood decay fungi," Int. Biodeterior. Biodegrad. 39(2-3), 199-205. DOI:10.1016/S0964-8305(97)00015-2

Williams, R. S. (2005). "Weathering of wood," in: Handbook of Wood Chemistry and Wood Composites, R. M. Rowell (ed.), CRC Press, New York, NY, pp. 142-185. 
Top Market Reports (2015). "Wood Coating Market by Coating Type (Stains \& Varnishes, Shellacs, Wood Preservatives \& Water Repellents), Application Method (Roll \& Brush Coating, Vacuum Coating, Spray Coating), End User (Furniture, Cabinets, Siding, Flooring \& Decking), \& by Region - Trends \& Forecast to 2020," (https://www.marketsandmarkets.com/new-reports.html), Accessed 25 January 2019.

Xu, G., Wang, L., Liu, J., and Hu, S. (2013). "Decay resistance and thermal stability of bamboo preservatives prepared using camphor leaf extract," Int. Biodeter. Biodegrad. 78, 103-107. DOI: 10.1016/j.ibiod.2012.12.001

Yamaguchi, H., and Okuda, K. (1998). "Chemically modified tannin and tannin-copper complexes as wood preservatives," Holzforschung 52(6), 596-602. DOI: 10.1515/hfsg. 1998.52.6.596

Yamaguchi, T., Fujita, K., and Sakai, K. (1999). "Biological activity of extracts from Cupressus lusitanica culture," J. Wood Sci. 45(2), 170-173. DOI: 10.1007/BF01192336

Yamaguchi, H., and Yoshino, K. (2005). "Influence of tannin-copper complexes as preservatives for wood on mechanism of decomposition by brown-rot fungus Fomitopsis palustris," Holzforschung 55(5), 464-470.

Yang, D.-Q., Wan, H., Wang, X.-M., and Liu, Z.-M. (2007). "Use of fungal metabolites to protect wood-based panels against mould infection," BioControl 52, 427-436. DOI: $10.1007 / \mathrm{s} 10526-006-9022-8$

Yang, D. Q. (2009). "Potential utilization of plant and fungal extracts for wood protection," For. Prod. J. 59, 97-103.

Zaremski, A., Gastonguay, L., and Prin, Y. (2011). "Natural protection of wood with antagonism fungi," ProLigno 7(1), 3-14.

Article submitted: November 6, 2018; Peer review completed: January 1, 2019; Revised version received and accepted: February 4, 2019; Published: February 8, 2019.

DOI: $10.15376 /$ biores.14.2.Teaca 